\title{
Büyükbaş hayvan dışkısı ve makroalg (Cladophora sp.)'den biyogaz üretimi
}

\author{
Biogas production from cattle manure and macroalgae (Cladophora sp.)
}

\author{
Serdar ÜÇOK ${ }^{1 \mathscr{O}}$ (D) , Ali AYBEK ${ }^{1}$ iD \\ ${ }^{1}$ Kahramanmaraş Sütçü Imam University, Faculty of Agriculture, Department of Biosystems Engineering, Kahramanmaraş, Turkey.
}

MAKALE BILGISI / ARTICLE INFO

\section{Makale tarihçesi / Article history:}

DOI: $10.37908 /$ mkutbd.837381

Geliş tarihi / Received:08.12.2020

Kabul tarihi/Accepted:18.02.2021

\section{Keywords:}

Cattle manure, macroalgae, biogas, biomethane, chemical analysis.

\footnotetext{
Corresponding author: Serdar ÜÇOK

$\bowtie:$ sucok@ksu.edu.tr
}

\section{ÖZET / A BSTR A C T}

Atıf / Citation: Üçok S, Aybek A (2021) Büyükbaş hayvan dışkısı ve makroalg (Cladophora sp.)'den biyogaz üretimi. MKU. Tar. Bil. Derg. 26(2) : 238-248. DOI: 10.37908/mkutbd.837381

\section{Giriş}

Günümüzde hayat standartlarının artması ve gelişen teknoloji ile enerjiye olan ihtiyaç her geçen gün artmaktadır. Enerji kaynakları, temel olarak iki gruptan oluşmaktadır. Bunlar; yenilenemeyen (fosil ve nükleer) ve yenilenebilir enerji kaynaklarıdır (Karaca, 2017).
Günümüz dünyasında ihtiyaç duyulan enerjinin çok büyük kısmı fosil kaynaklardan (kömür, petrol ve doğal gaz) karşılanmaktadır (IEA, 2013; Delborne ve ark., 2020; Höök, 2020). Fosil enerji kaynakları diğer enerji kaynaklarına göre ucuz olmalarının yanı sıra üretim teknolojisindeki gelişmelerden kaynaklı olarak da geniş kullanım alanına sahiptir. Sanayi devriminden sonra 
kömüre dayalı olan enerji ihtiyacı, teknolojinin gelişmesiyle beraber petrol ve doğal gaz kaynaklı enerjiler gereksinimi karşılamaya başlamıştır. Fakat, 1976 yılında meydana gelen petrol krizinden sonra bu tarz fosil kaynaklı enerji türlerine güven sorunu oluşmaya başlamıştır (Gürbüz, 2009; Dok ve ark., 2019). Bu krizden sonra teknolojik ve maddi olarak gelişmiş olan lider dünya ülkeleri, yeni enerji kaynakları araştırmaya başlamışlardır. Ayrıca fosil kaynaklı enerji türlerinin çevre kirliliğine olan etkisinin fazla olması nedeniyle de araştırmalar hız kazanmıştır. Araştırmalar sonucunda fosil yakıtlarla rekabet etmesi zor görünmesine rağmen az kullanılan ve ikinci planda bırakılan yenilenebilir enerji kaynakları giderek önem kazanmaya başlamıştır. Yenilenebilir enerji kaynakları, doğanın kendi evrimi içerisinde sonraki gün aynı şekilde mevcut olabilen temiz ve çevre kirliliği oluşturmayan, güneş enerjisi, rüzgar enerjisi, jeotermal enerji, hidrolik enerji, hidrojen enerjisi, deniz kökenli enerjiler ve biyokütle enerjisinden oluşmaktadır (Güneş, 1999; Oktit, 2000). Biyokütle enerjisi, temiz, çevreci olması ve enerji verimliliğinin yüksek olmasından kaynaklı olarak yenilenebilir enerji kaynakları arasında önemli bir yer tutmaktadır. Biyokütle, yeşil bitkilerin güneş enerjisini fotosentez yolu ile kimyasal enerjiye dönüştürerek, depolamasıyla ortaya çıkan ve canlı organizmaların kökeni olarak da meydana gelen organik madde kaynağı şeklinde tanımlanmaktadır (Yorgun ve ark., 1998).

Enerji üretiminde kullanılan biyokütle kaynakları; bitkisel, hayvansal, kentsel ve endüstri kaynaklı olan atıklar ve yan ürünlerden oluşmaktadır (Sun ve ark., 1980; Yorgun ve ark., 1998). Biyokütleden biyoetanol, biyogaz, biyodizel, briket, pelet ve birçok yakıt türü meydana gelmektedir (Kapluhan, 2014). Biyokütle içerisinde daha yararlı, çevreci olması ve enerji verimliliğinin yüksek olmasından kaynaklı olarak kullanılan biyogaz, gaz ve ileri teknolojik dönüşümle sıvı formlarında elde edilebilen biyoyakıt türündendir (Wilkie, 2018). Biyogaz, anaerobik madde fermantasyonunun bir türü olarak oluşan ve içeriğindeki organik maddeye bağlı olarak, \%60-75 metan $\left(\mathrm{CH}_{4}\right)$, \%2338 karbondioksit $\left(\mathrm{CO}_{2}\right)$, eser miktarda hidrojen $\left(\mathrm{H}_{2}\right)$ ve hidrojen sülfür $\left(\mathrm{H}_{2} \mathrm{~S}\right)$ bulunan bir gaz karışımı olarak tanımlanmaktadır (Bukvic ve ark., 2002; Aybek ve ark., 2015: Üçok, 2016).

Türkiye hem hayvansal hem de bitkisel üretim açısından yüksek potansiyele sahip önemli bir tarım ülkesi konumundadır. Hayvansal ve bitkisel üretim fazlalığından kaynaklı olarak organik materyal potansiyelinin yüksek olmasına karşın bu oluşan atıkların enerjiye dönüştürülmesinde yaygın olarak kullanılan biyogaz teknolojisi gerektiği gibi değerlendirilememektedir. Türkiye ihtiyaç duyduğu enerjinin büyük bir bölümünü ithal ederek karşılamaktadır. Ayrıca nüfus ve sanayileşmenin artış oranına bağlı olarak artan enerji ihtiyacını karşılamak amacı ile alternatif enerji kaynaklarının kullanılmaya başlanılması ve bu enerji türlerine yatırım yapılmasının önemi de yükselmeye başlamıştır. Türkiye'de hayvancılığın yaygın olması ve tarımsal üretiminin de yüksek olmasından dolayı tarımsal materyallerin biyogaz üretimi üzerine araştırma çalışmaları önem kazanmaya başlamıştır. Canlı hayvan üretiminin artmasına bağlı olarak çok fazla organik dışkı oluşmakta ve bu dışkıların yönetiminin uygun yapılamaması önemli çevre ve sağlık problemlerini meydana getirmektedir. Oluşan risk ve zararları en az düzeye indirmek için bu atıkların doğru yönetimi ve kullanımı da önem arz etmektedir.

Türkiye İstatistik Kurumu verilerine göre 2019 yılında Türkiye'de 14.523 milyon büyükbaş hayvan bulunmaktadır (TÜiK, 2019). Bu verilere dayanarak, Türkiye'de büyükbaş hayvan dışkı potansiyeli yaklaşık 621.473 milyon ton yıl $^{-1}$ olmaktadır. Kahramanmaraş ili Elbistan ilçesi Ceyhan Kaynağı Pınarbaşı göleti; Afşin Elbistan A-Termik Santralinin soğutma suyu ihtiyacı, ilçenin içme suyu, tarımsal sulama ve yöre halkı için önemli mesire alanı haline gelmiştir. Ancak, gölette bentin yüseltilmesiyle yüzeyin genişlemesi sonucu çizgisel akış hızının düşmesi, sedimentteki fosfor oranının sudan yüksek olması ve ötrofikasyonun olmasıyla gölette aşırı makroalg (yosun) oluşmaktadır. Bundan kaynaklı olarak su yüzeyi bir battaniye görünümünde kapanmaktadır. Bu yosun Cladophora sp. makroalg türüdür (Demir ve ark., 2003). Kuraklığın artmasına bağlı olarak kaynak sularının azalmasıyla birlikte gölet yüzeyinde yüksek derecede oluşan makroalg materyalleri kirlilik ve kötü koku meydana getirip çevre açısından ciddi problemlere neden olmaktadır. Söz konusu atıklar yenilendiğinden, yörenin çevresel sorunlarına yük katmaktadır. Bu makroalgler organik materyaller olduğundan, biyogaz üretimi için kullanılabilir. Böylece çevresel sorunların giderilmesi yanında enerji üretimi de sağlanabilir.

Günümüzde organik materyallerin biyogaz ve metan potansiyellerinin belirlenmesiyle ilgili birçok çalışma yapılmaktadır. Organik materyallerin özgül biyogaz ve metan üretimlerinin yüksek olmasında, enerji girdisi ve ekonomik getirisinin daha yüksek olacağı, yapılan birçok araştırmada mevcuttur. Türkiye bir tarım ve hayvancılığa dayalı ülke olmasından dolayı tarımsal ve tarıma dayalı endüstri materyalleri biyogaz üretiminde önemli bir hammadde oluşturmaktadır. Anaerobik fermantasyon ile atık materyallerin biyogaza dönüştürülmesi dünyada en ekonomik ve yararlı uygulamalardan biridir. Biyogaz 
ve metan üretiminin artırılması için bitkisel materyaller hayvansal materyallere karıştırılarak anaerobik fermantasyon işlemine tabi tutulmaktadır Farklı materyallerin belli oranlarda karıştırılarak anaerobik fermantasyon işlemi uygulanmasına ko-fermantasyon denilmektedir.

$\mathrm{Bu}$ çalışmanın genel amacı biyogaz tesisleri için hammadde olarak kullanılabilecek büyükbaş hayvan dışkısı ve makroalglerden, en uygun karışım oranlarında, ko-fermantasyonu ile biyogaz ve metan verimlerinin belirlenmesidir.

Araştırmanın spesifik amaçları ise şunlardır;

- Büyükbaş hayvan dışkısı ve makroalgin kimyasal analizlerinin belirlenmesi,

- Büyükbaş hayvan dışkısı ve makroalgin $\mathrm{C} \mathrm{N}^{-1}$ na göre karışım oranlarının belirlenmesi,

- BMP (biyometan potansiyel) denemelerinde, \%7 kuru madde oranındaki; metan oranları, günlük biyogaz ve metan üretimi, kümülatif biyogaz ve metan üretimi ve özgül metan üretiminin belirlenmesi,

BMP denemelerinde, çalışma başlangıcında ham materyallerin ve anaerobik fermantasyon sonucu oluşan biyogaz cürufunun kimyasal kompozisyonlarının (karbon $(\mathrm{C})$, azot $(\mathrm{N}), \mathrm{C} \mathrm{N}^{-1}$, kuru madde $(\mathrm{KM})$, organik kuru madde (OKM), pH, elektriksel iletkenlik (EC), kimyasal oksijen intiyacı (KOi), nötr deterjanda çözünmeyen lif (NDF) ve asit deterjanda çözünmeyen lif (ADF) belirlenmesidir.

\section{MATERYAL ve YÖNTEM}

Araştırma kapsamında büyükbaş hayvan dışkısı ve makroalg kullanılmıştır. Büyükbaş hayvan dışkısı (Şekil 1a) Isparta Uygulamalı Bilimler Üniversitesi, Tarımsal Uygulama ve Araştırma Merkezi Süt Sığırcılığı i̇şletmesi'nden, makroalg (Şekil 1b) ise Kahramanmaraş ili Elbistan Pınarbaşı Ceyhan su kaynağındaki su yüzeyinden temin edilmiştir.

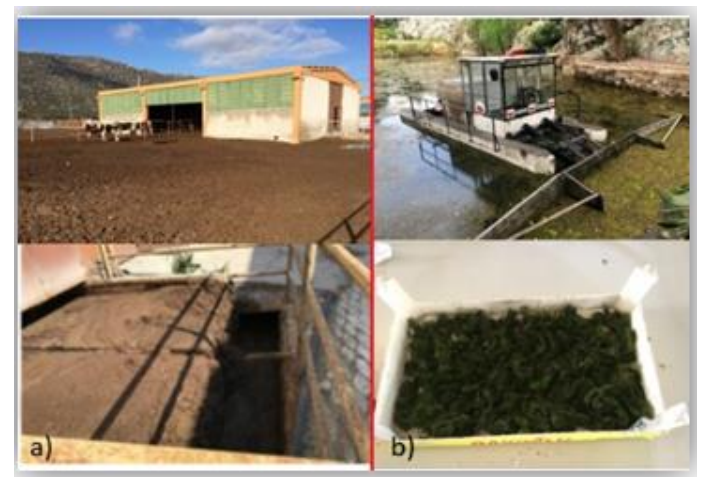

Şekil 1. Büyükbaş hayvan dışkısı (a) ve makroalg (b)

Figure 1. Cattle manure (a) and macroalgae (b)
Çalışmada kullanılan makroalg, 2018 yılı Şubat-Mart aylarında yaklaşık iki haftalık sürede, güneş enerjili kurutma sisteminde kurutulup $1 \mathrm{~mm}$ 'lik elekten geçirilerek öğütülmüştür. Büyükbaş hayvan dışkısı ise çiftlikten sıyırıcının topladığı alandaki karışımdan alınarak işleme tabi tutulmadan denemeye alınmıştır.

Besleme materyallerinin toplam kuru madde oranları \%6-13 arasında olması durumunda, biyogaz eldesinde en verimli üretim gerçekleştirilmektedir (Sarapatka, 1993). Bu çalışmada kullanılan besleme materyallerinin kuru madde oranı BMP test ünitesi işletimi açısından en uygun aralık olan \%7 kuru madde oranı alınmıştır. Elde edilen makroalg ve büyükbaş hayvan dışkı materyalleri; $\% 7$ kuru madde oranında, $\mathrm{C} \mathrm{N}^{-1}$ değerine göre 5 farklı karışım (Karışım-1, Karışım-2, Karışım-3, Karışım-4, Karışım-5) oluşturulmuştur. BMP test ünitesindeki cam şişeler su banyosuna yerleştirilmeden önce, test ünitesinin gaz sızdırmazlık testi yapılmıştır (Onursal, 2016; Ekinci, 2018). Daha sonra elde edilen bu karışımlar 2 L'lik otoklav cam şişelere doldurulup BMP test ünitesindeki (Şekil 2) su banyosu içerisinde yer alan bölmelere yerleştirilmiştir.

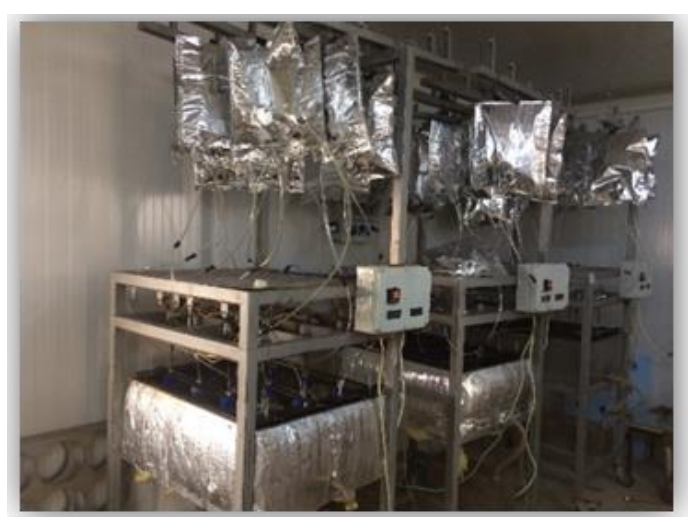

Şekil 2. BMP test ünitesi

Figure 2. BMP test unit

Her bir karışım 3 tekerrür olarak alınmıştır. BMP denemeleri, test ünitesi için en uygun olan, bakteri gruplarının optimum üreme ve çalışma sıcaklığı olan 37 ${ }^{\circ} \mathrm{C}$ sıcaklıkta, 60 gün süre boyunca yürütülmüştür. Şeffaf hortum boruları sayesinde cam şişeler içerisinde oluşan biyogaz, 5 L'lik biyogaz torbalarına iletilmiştir. Biyogaz torbalarının dolmasıyla ölçümler yapılmıştır. Ölçümler; 3 , $5,8,13,18,26,38$ ve 60 . Günlerde, ritter marka volümetrik biyogaz sayacı kullanılarak biyogaz miktarı, draeger 7000 marka sensörler aracılığı ile biyogaz içerisinde oluşan metan oranı belirlenmiştir. Tüm üretimlerden aşı'nın ürettiği biyogaz değerleri çıkarılmıştır (Eşitlik 1). 


$$
\mathrm{BMP}_{\text {net }}=\frac{\mathrm{V}_{\mathrm{R}}-\mathrm{V}_{\mathrm{I}}}{\mathrm{M}_{\mathrm{S}}} \ldots \ldots \ldots \ldots \ldots \ldots \ldots \ldots \ldots \text { Eşitlik (1) }
$$

Burada;

$$
\begin{array}{ll}
\mathrm{BMP}_{\text {net }} & \text { : Net gaz üretimi (L/kg) } \\
\mathrm{V}_{\mathrm{R}} & \text { : Reaktörde oluşan gaz (L) } \\
\mathrm{V}_{\mathrm{I}} & \text { : Aşıda oluşan gaz (L) } \\
\mathrm{MS}_{\mathrm{S}} & \text { : Substrat miktarı (kg)'dır. }
\end{array}
$$

Kuru madde esaslı hazırlanan karışım oranları Eşitlik 2 (Sarapatka, 1993) ile belirlenmiştir.

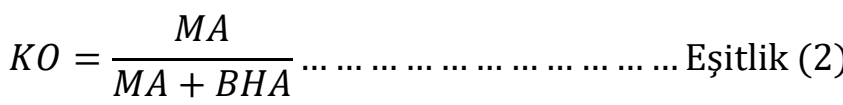

Burada;

KO : Kuru madde oranı (\%)

MA : Makroalg (kg)

BHA : Büyükbaş hayvan dışkısı (kg)

Curuf parametrelerinin kimyasal analizleri (karbon (C), azot $(\mathrm{N}), \mathrm{C} \mathrm{N}^{-1}$, kuru madde (KM), organik kuru madde $(\mathrm{OKM}), \mathrm{pH}$, elektriksel iletkenlik (EC), kimyasal oksijen ihtiyacı (KOi), nötr deterjanda çözünmeyen lif (NDF) ve asit deterjanda çözünmeyen lif (ADF)), deney başlangıcında (B) ve 60 günlük anaerobik fermantasyon sonucunda (S) belirlenmiştir.

Kuru madde analizi, ham kül ve organik madde içeriği (AOAC, 1990)'e göre, NDF ve ADF analizi (Vansoset ve ark., 1991)'e göre, KOi değerleri analizi (ISO 6060, 1986) standardına göre, $\mathrm{pH}$ değerleri 0.1 hassasiyetli inolab $\mathrm{pH}$ 720 sensörlerle, EC değerleri ise Multi 340i sensörleri, C $\mathrm{N}^{-1}$ oranı ise vario marka elemental cihazı ile belirlenmiştir.

\section{BULGULAR ve TARTIŞMA}

Çalışmada kullanılan büyükbaş hayvan dışkısı ve makroalgin, kimyasal analizleri Çizelge 1'de verilmiştir. Buna göre büyükbaş hayvan dışkısı için C \%32.09, N $\% 2.13, \mathrm{C} \mathrm{N}^{-1} 15.03$, KOI $40274 \mathrm{mg} \mathrm{L}^{-1}$, EC $10.65 \mu \mathrm{Sm}^{-1}$, $\mathrm{pH} 7.24, \mathrm{KM} \% 82.10$, OKM \%84.45, ADF\%34.63 ve NDF değeri ise \%68.71 olarak makroalg için $\mathrm{C} \% 23.03, \mathrm{~N}$ $\% 1.98, \mathrm{C} \mathrm{N}^{-1} 11.67$, KOI $16070 \mathrm{mg} \mathrm{L}^{-1}$, EC $9.17 \mu \mathrm{S} \mathrm{cm}^{-1}, \mathrm{pH}$

\begin{tabular}{|c|c|c|c|c|c|c|c|c|c|c|}
\hline Materyaller & $\% \mathrm{C}$ & $\% \mathrm{~N}$ & $\mathrm{CN}^{-1}$ & KOI $\left(\mathrm{mgL}^{-1}\right)$ & $\begin{array}{c}E C \\
\left(\mu \mathrm{S} \mathrm{cm}^{-1}\right)\end{array}$ & $\mathrm{pH}$ & $\% \mathrm{KM}$ & $\% O K M$ & $\% A D F$ & $\%$ NDF \\
\hline Büyükbaş hayvan dışkısı & 32.09 & 2.13 & 15.03 & 40274 & 10.65 & 7.24 & 82.10 & 84.45 & 34.63 & 68.71 \\
\hline Makroalg & 23.03 & 1.98 & 11.67 & 16070 & 9.17 & 7.60 & 12.23 & 59.60 & 20.89 & 36.54 \\
\hline
\end{tabular}
7.60, KM \%12.23, OKM \%59.60, ADF \%20.89 ve değeri ise NDF \%36.54 olarak belirlenmiştir (Çizelge 1).

Çizelge 1. Büyükbaş hayvan dışkısı ve makroalgin kimyasal analizleri

Table 1. Cattle manure and chemical analysis of macroalgae

Materyallerin karışım oranları $\mathrm{C} \mathrm{N}^{-1}$ oranına göre belirlenerek Çizelge $2^{\prime}$ de verilmiştir. $\mathrm{C} \mathrm{N}^{-1}$ oranı $10.98-$ 15.75 arasında değişmektedir. Karışımlarda 1'den 5'e doğru büyükbaş hayvan dışkı oranı artıkça $\mathrm{C} \mathrm{N}^{-1}$ değeri de artmıştır. \%7 kuru madde oranındaki hazırlanan karışımlar; Karışım-1 (\%100 Makroalg), Karışım-2 (\%69

Çizelge 2. Besleme materyallerinin karışım oranları

Table 2. Mixing ratios of feed materials

\begin{tabular}{ccccccc}
\hline Karışımlar & $\mathrm{C} \mathrm{N}^{-1}$ & Nem & $\begin{array}{c}\text { Büyükbaş } \\
\text { hayvan dışkısı }\end{array}$ & Makroalg & $\begin{array}{c}\text { Aşı } \\
\text { Materyallerin } \\
\text { karışım oranı }\end{array}$ \\
\hline Karışım-1 & - & $\%$ & $\mathrm{~kg} / \mathrm{kg}$ & $\mathrm{kg} / \mathrm{kg}$ & $\mathrm{kg} / \mathrm{kg}$ & - \\
Karışım -2 & 10.98 & 93.00 & 0.000 & 0.490 & 0.462 & 1.00 \\
Karışım -3 & 12.17 & 93.00 & 0.163 & 0.356 & 0.462 & 0.69 \\
Karışım -4 & 13.37 & 93.00 & 0.314 & 0.230 & 0.462 & 0.42 \\
Karışım -5 & 14.56 & 93.00 & 0.457 & 0.112 & 0.462 & 0.20 \\
\hline
\end{tabular}

Araştırmada, metan oranı Şekil 3'de, günlük biyogaz üretimi Şekil 4'de, günlük metan üretimi Şekil 5'de, kümülatif biyogaz üretimi Şekil $6^{\prime}$ da, kümülatif metan
Makroalg+\%31 Büyükbaş hayvan dışkısı), Karışım-3 (\%42 Makroalg+\%58 Büyükbaş hayvan dışkısı), Karışım-4 (\%20 Makroalg+\%80 Büyükbaş hayvan dışkısı) ve Karışım-5 (\%100 Büyükbaş hayvan dışkısı)'den oluşmaktadır (Çizelge 2). 
BMP denemelerinde, tüm karışımların zamana bağlı biyogaz değerleri içerisindeki metan $\left(\mathrm{CH}_{4}\right)$ oranı; 1-10. günler arasında hızla artarak 13. günde en yüksek düzeye (\%50-60) ulaşmış, 10-60. günler arasında ise çok düşük bir azalmayla \%47-50 düzeyine inmiştir. Karışımlar içerisinde en yüksek metan oranı (\%62) Karışım-4' de elde edilmiştir. Bunu sırsıyla Karışım-5 (\%60), Karışım-3 (\%57), Karışım-2 (\%56) ve Karışım-1 (\%52) izlemiştir (Şekil 3).

BMP denemeleri ile yapılan araştırmalarda biyogaz içerisindeki metan oranını; Onursal (2014), büyükbaş hayvan dışkısı ve gül işleme atıklarından, \%25-75, Montingelli ve ark. (2016), Laminaria spp. türündeki makroalg için \%40-60, Korkmaz (2017), makroalgden maksimum \%55.1, Ekinci ve ark. (2018), aspir ve büyükbaş hayvan dışkı materyallerinden maksimum $\% 64$, Beily ve ark. (2019), koyun dışkısından \%55 olarak belirlemişlerdir.

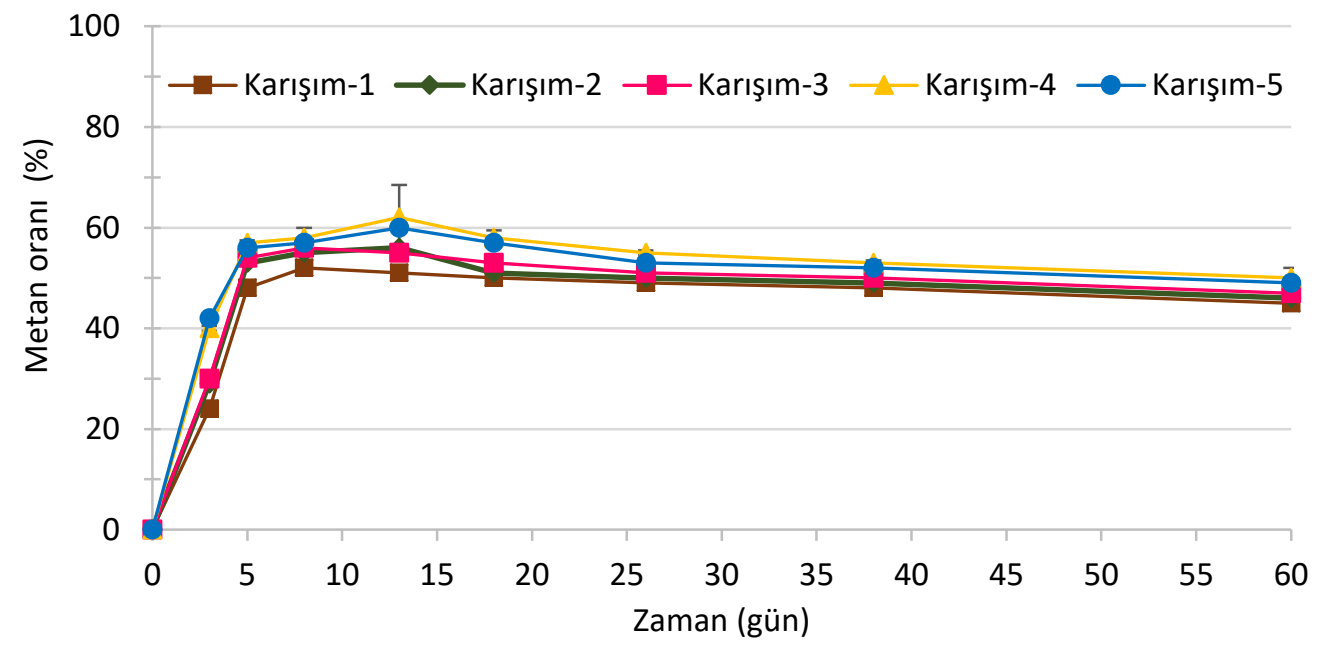

Şekil 3. Karışımların metan oranları

Figure 3. Methane ratio of mixtures

Tüm karışımlarda, günlük biyogaz üretimi; 1-8. günler arasında hızlı bir artış göstererek, 8. günde maksimum (0.60-1.51 L kg OKM gün-1) değerlere ulaşmış, 8-38. günler arasında hızlı bir azalış göstermiş, 38-60. günler arasında ise çok düşük bir azalma göstererek 60. günde en düşük düzeye (0.01-0.1 L kg OKM gün-1) ulaşmıştır. Günlük maksimum biyogaz üretimi, Karışım-4'de (1.51 L gün $^{-1}$ ) oluşmuştur. Bunu sırası ile Karışım-5-3-2-1 izlemiştir (Şekil 4).

Aynı yöntemi kullanarak, biyogaz üretimini; Montingelli ve ark. (2016), Laminaria spp. türündeki makroalgde 0.64 L kg OKM ${ }^{-1}$ gün; Ekinci ve ark. (2018), \%26 büyükbaş hayvan dışkısı+ \%74 aspir karışımında $1.70 \mathrm{~L} \mathrm{~kg} \mathrm{OKM}^{-1}$ gün; Ferrentino ve ark. (2019), atık sulardan $0.6 \mathrm{~L} \mathrm{~kg}$ $\mathrm{OKM}^{-1}$ gün olarak belirlemişlerdir.

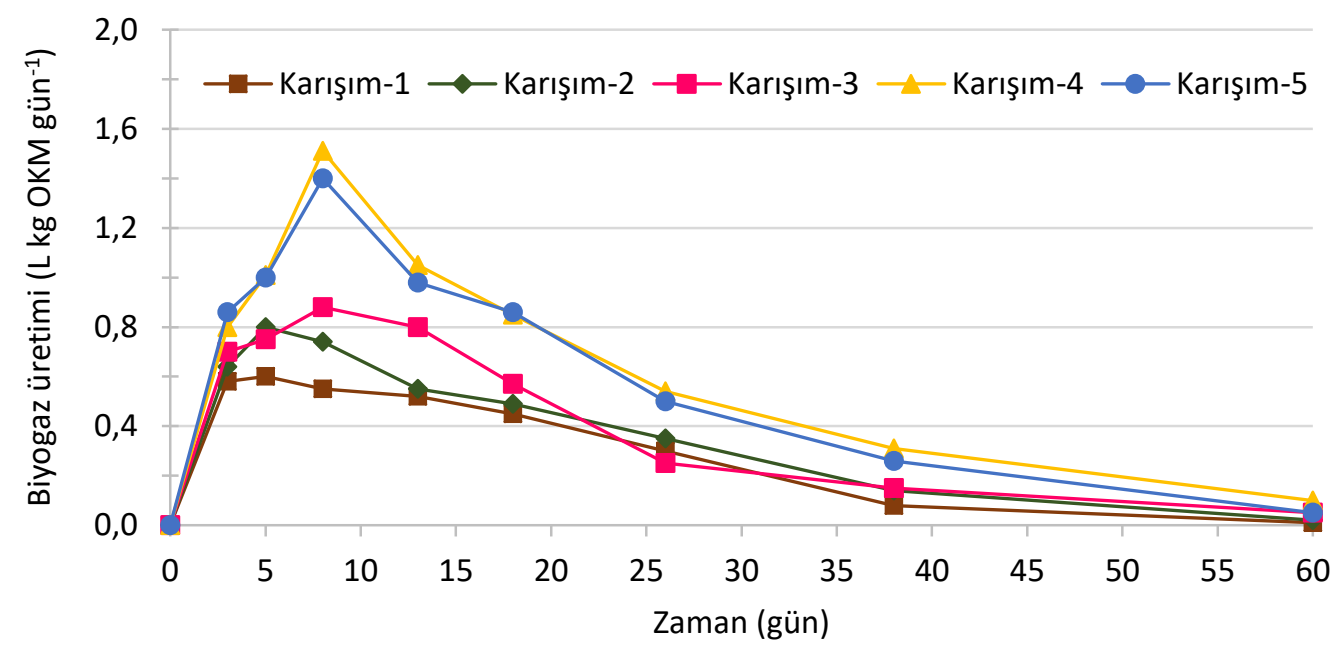

Şekil 4. Karışımların günlük biyogaz üretimi

Figure 4. Daily biogas production of mixtures 
Tüm karışımların, BMP denemelerine göre günlük metan üretimi, 1-8. günler arasında hızlı bir artış göstererek 8 . günde maksimum düzeye ulaşmış, devamında 38 . güne kadar hızlı azalma ve 60. günde en düşük düzeye (0.01$0.06 \mathrm{~L} \mathrm{~kg} \mathrm{OKM} \mathrm{gün}{ }^{-1}$ ) ulaşmıştır. Günlük maksimum $\mathrm{CH}_{4}$ üretimi, Karışım-4' de (0.91 L kg OKM gün-1) oluşmuştur. Bunu sırası ile Karışım-5-3-2-1 izlemiştir (Şekil 5).

Farklı materyallerden metan üretimini; Roesijadi ve ark.
(2010), Laminaria türündeki makroalg için $0.23-0.30 \mathrm{~m}^{3}$ kg gün ${ }^{-1}$, gracilaria türündeki makroalg için $0.25-0.31 \mathrm{~L} \mathrm{~kg}$ OKM gün ${ }^{-1}$; Montingelli ve ark. (2016), Laminaria spp. türündeki makroalglede $0.35 \mathrm{~L} \mathrm{~kg} \mathrm{gün}{ }^{-1}$; Ekinci ve ark. (2018), büyükbaş hayvan dışkısı ve aspirde 0.95 L kg OKM gün $^{-1}$; Ferrentino ve ark. (2019), atık sulardan $0.32 \mathrm{~L} \mathrm{~kg}$ OKM gün ${ }^{-1}$ olarak saptamışlardır.

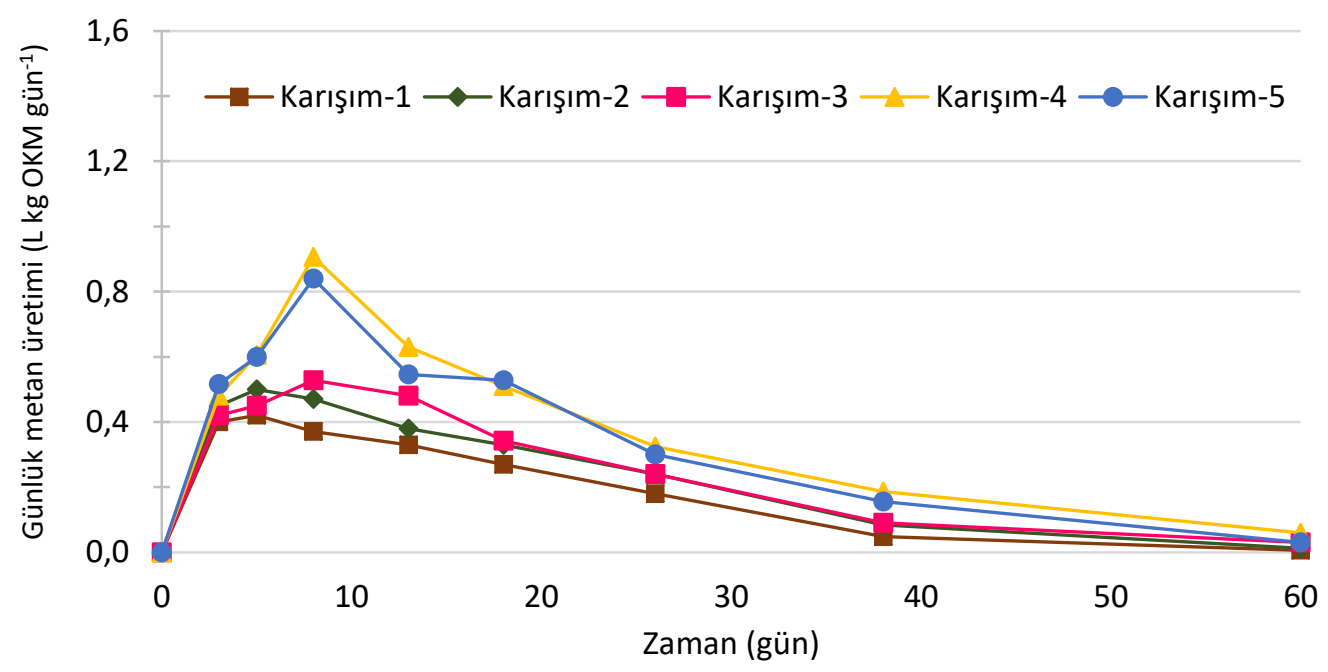

Şekil 5. Karışımların günlük metan üretimi

Figure 5. Daily methane production of mixtures

Tüm karışımlarda oluşan kümülatif biyogaz üretimi; 1-26. günlerde hızlı, devamında ise küçük miktarlarda artarak 60. günde maksimum değerlere (14.87-27.67 L) ulaşılmıştır. Biyogaz üretim miktarları Karışım-1'de 214.87 L, Karışım-2'de 2.47-18.74 L, Karışım-3'te 3.4722.51 L, Karışım-4'te 2.87-27.67 L ve Karışım-5'te 3.27-
26.24 L olarak belirlenmiştir. Karışımlar arasında kümülatif biyogaz miktarı en fazla $27.67 \mathrm{~L}$ ile Karışım-4'te meydana gelirken en az ise 14.87 L ile Karışım-1'de oluşmuştur (Şekil 6). Ekinci ve ark. (2018), \%26 büyükbaş hayvan dışkısı+\%74 aspir karışımında kümülatif biyogaz üretimi $28 \mathrm{~L}$ olarak belirlemişlerdir.

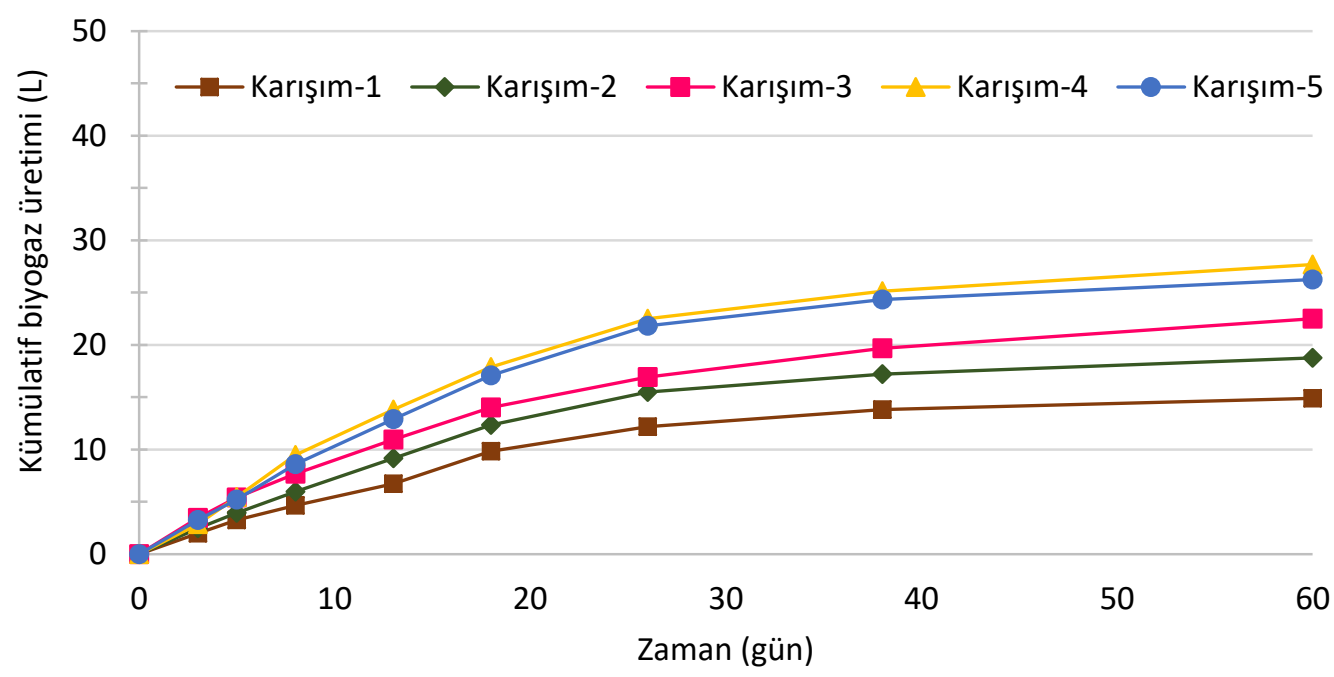

Şekil 6. Karışımların kümülatif biyogaz üretimi

Figure 6. Cumulative biogas production of mixtures 
Tüm karışımlarda oluşan kümülatif metan değerleri, biyogaz üretiminde olduğu gibi; 1-26. günlerde hızlı, devamında ise küçük miktarlarda artarak 60. günde maksimum (8.74-15.77 L) düzeye ulaşmıştır. Karışımlar arasında kümülatif metan miktarı en fazla $15.77 \mathrm{~L}$ ile Karışım-4'te meydana gelirken en az ise $1.15 \mathrm{~L}$ ile Karışım-1' de oluşmuştur (Şekil 7).
Onursal (2016), büyükbaş hayvan dışkısı ve gül işleme atıkları için metan üretimi 9 L; Ekinci ve ark. (2018), büyükbaş hayvan dışkısı ve aspir materyalleri karışımı için BMP kümülatif metan üretimi 10.68-15.77 L olarak belirlemişlerdir. Bu araştırmada elde edilen kümülatif metan değeri Ekinci ve ark. (2018) ile benzer olurken, Onursal (2016)'dan ise yüksek olmaktadır.

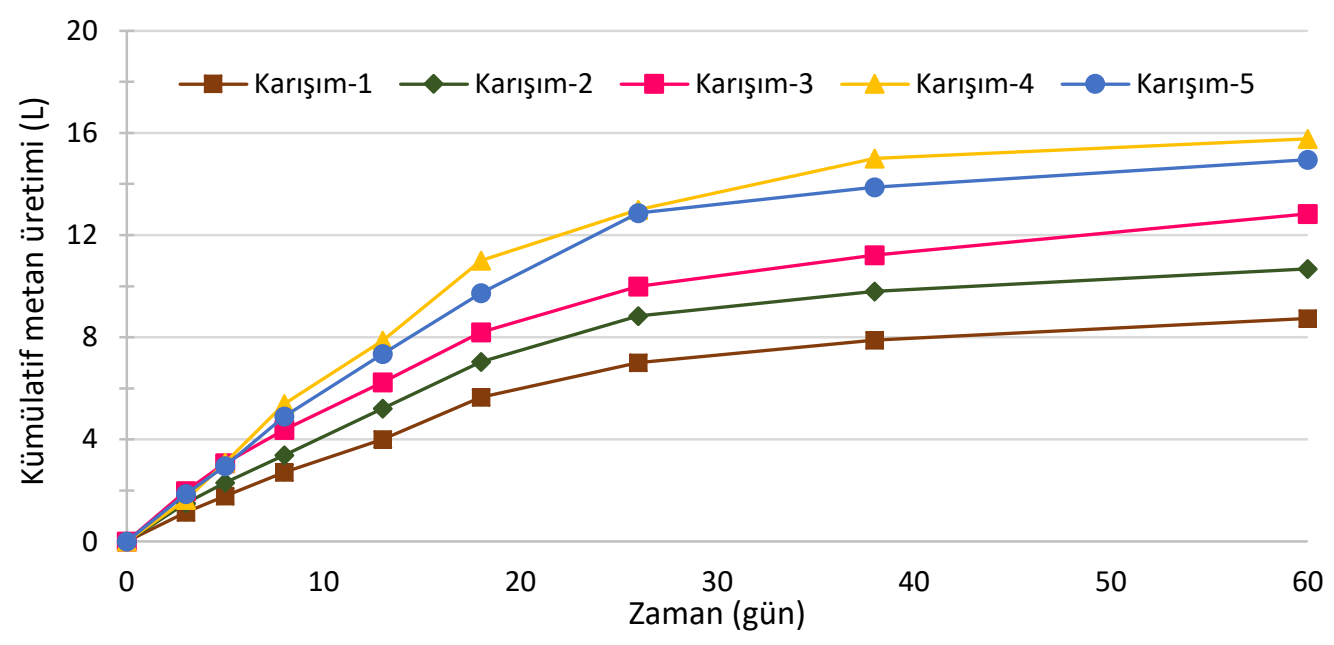

Şekil 7. Karışımların kümülatif metan üretimi

Figure 7. Cumulative methane production of mixtures

Tüm karışımlarda özgül metan üretimi 1-26. günlerde hızlı bir artış, 26-38. günlerde en yüksek özgül metan üretimi gerçekleştiren Karışım-4 aynı hızda artış gösterirken, diğer karışımlar daha düşük oranlarda artış göstermekte, devamında ise tüm karışımlardaki artış oranı düşük miktarda devam ederek 60. günde maksimum düzeye $\left(137.00,186.41 \mathrm{~N} \mathrm{~mL} \mathrm{gOM}^{-1}\right)$ ulaşmıştır. Özgül metan üretimi, Karışım-1'de 10.60-137 $\mathrm{NmL}$ gOM $^{-1}$, Karışım-2' de 15.24-149.21 NmL gOM-1, Karışım-3'te 12.67-157.13 NmL gOM-1, Karışım-4'te 16.86-186.41 NmL gOM ${ }^{-1}$, Karışım-5'te ve 14.56-175.32 $\mathrm{NmL} \mathrm{gOM}^{-1}$ olarak belirlenmiştir. En yüksek özgül metan üretimi Karışım-4 de (186.41 NmL gOM $^{-1}$ ) oluşmuştur.
Bunu sırası ile Karışım-5 (175.32 NmL gOM ${ }^{-1}$ ), Karışım-3 (175.32 $\mathrm{NmL} \mathrm{gOM}^{-1}$ ), Karışım-2 (149.21 NmL gOM ${ }^{-1}$ ) ve Karışım-1 (137 NmL gOM ${ }^{-1}$ ) izlemiştir.

Oliveria ve ark. (2014), Gracilaria vermiculophylla türündeki makroalgi ön işlemli olarak, ko-fermantasyonu ile metan üretimini $295 \mathrm{NmL}_{\text {gOM }}{ }^{-1}$ olarak, Korkmaz (2017), makroalgin metan üretimini $147-167 \mathrm{NmL} \mathrm{gOM}^{-}$ 1 , Ekinci ve ark. (2018) ise büyükbaş hayvan dışkısı ve aspir karışımından özgül metan üretimini 167-205 NmL gOM $^{-1}$ olarak belirlemişlerdir. Bu araştırmada bulunan değerler, Oliveria ve ark. (2014)'den düşük bulunmuş, Korkmaz (2017) ve Ekinci ve ark. (2018) ile benzer düzeyde bulunmuştur.

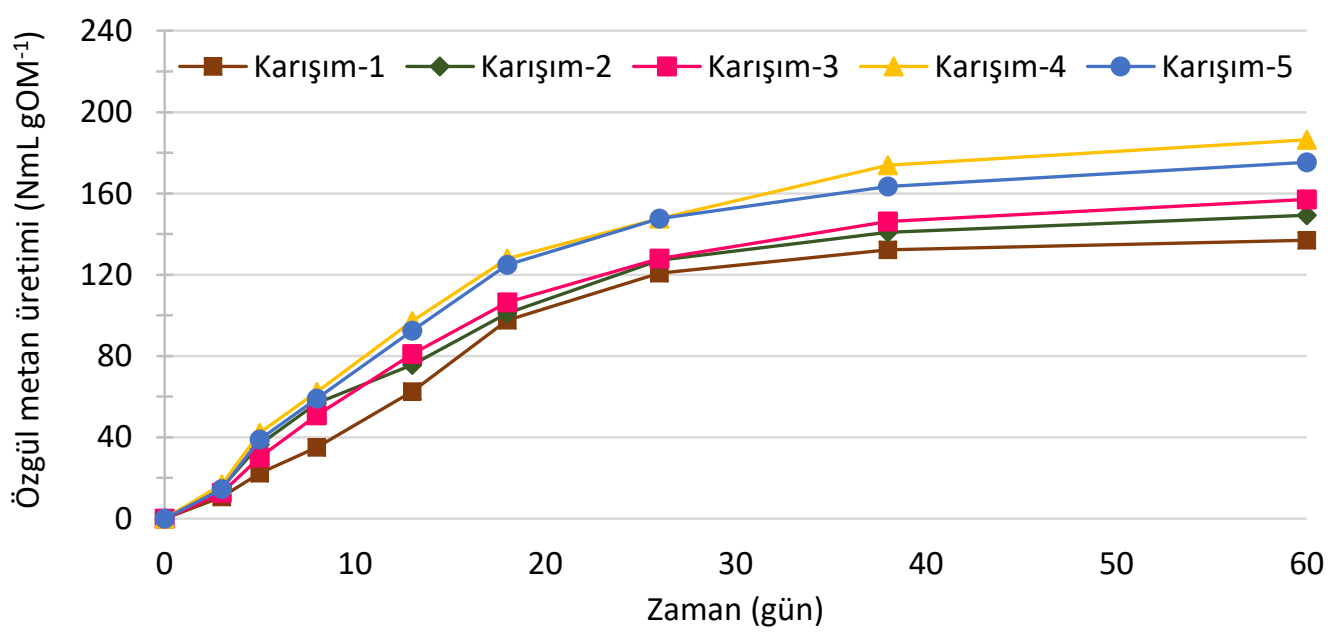

Şekil 8. Karışımların özgül metan üretimi

Figure 8. Specific methane production of mixtures 
Yapılan bu araştırmada metan ve biyogaz üretimlerinin diğer araştırmalarda farklıık göstermesinin nedeni, kimyasal içerik, ko-fermantasyon, sıcaklık, karıştırma, ön işlem, hayvanın cinsi, kuru madde oranı, materyal türleri ve yükleme oranlarından kaynaklandığı söylenebilir.

BMP denemelerinde; metan oranı, günlük biyogaz üretimi, günlük metan üretimi, kümülatif biyogaz üretimi, kümülatif metan üretimi ve özgül metan üretiminde karışımlar arasında önemli farklıık görülmüştür $(P<0.05)$.

Biyogaz parametrelerinin (metan oranı, günlük biyogaz üretimi, günlük metan üretimi, kümülatif biyogaz üretimi, kümülatif metan üretimi, özgül metan üretimi) en yüksek değerleri Karışım-4'de, en düşük değerleri ise Karışım-1'de oluşmuştur (Çizelge 3 ).
Araştırma'da metan ve biyogaz üretimi en yüksek Karışım-4'de meydana gelmesinin sebebi kofermantasyon sonucu mikrobiyal sinbiyotik ilişki olmasından kaynaklanabilir. Bakterilerin gelişmesi, üremesi için makro ve mikro besin açısından en uygun ortamda gaz üretimi artmaktadır. Kimyasal analiz sonuçlarına göre en fazla $\mathrm{C}, \mathrm{N}, \mathrm{KM}, \mathrm{OKM}, \mathrm{KO}$ giderimi, ADF ve NDF'nin azalması Karışım-4'de meydana gelmiştir. Bakteriler, uygun ortamda besin, element ve lignoselülozikleri kullanarak gaz üretimini ve metan oranını artırabilir (Tabatabaei ve ark., 2020). Bundan kaynaklı olarak besinsel elementlerin en fazla kullanıldığı en iyi verim Karışım-4'te gerçekleşmiş olabilir.

Çizelge 3. BMP denemelerinde biyogaz parametrelerinin ortalama değerleri ve önem testi*

Table 3. Average values and significance test of biogas parameters in BMP trials

\begin{tabular}{|c|c|c|c|c|c|}
\hline Değişkenler & Karışım-1 & Karışım-2 & Karışım-3 & Karışım-4 & Karışım-5 \\
\hline Metan oranı & $49.62 \mathrm{e}$ & $51.66 \mathrm{~d}$ & $52.37 c$ & $56.43 a$ & $54.74 b$ \\
\hline Günlük biyogaz üretimi & $0.53 e$ & $0.62 d$ & $0.70 c$ & $0.99 a$ & $0.95 b$ \\
\hline Günlük metan üretimi & $0.34 \mathrm{e}$ & $0.40 d$ & $0.43 c$ & $0.60 a$ & $0.57 b$ \\
\hline Kümülatif biyogaz üretim & $15.25 \mathrm{e}$ & $19.14 d$ & $23.06 c$ & $27.89 a$ & $26.94 b$ \\
\hline Kümülatif metan üretim & $8.74 \mathrm{e}$ & $10.85 d$ & $13.11 \mathrm{c}$ & $15.90 a$ & $15.33 b$ \\
\hline Özgül metan üretim & $139.62 \mathrm{e}$ & $150.17 d$ & $159.72 c$ & 189.39a & $180.80 \mathrm{~b}$ \\
\hline
\end{tabular}

*: Satır içerisinde aynı harfleri alan değerler arasında istatiksel olarak anlamlı bir fark yoktur $(P<0.05)$.

Çizelge 4. BMP denemesi deney başlangıç ve sonrası kimyasal analizleri Table 4. Chemical analysis of BMP experiment start and after

\begin{tabular}{|c|c|c|c|c|c|c|c|}
\hline \multirow{2}{*}{ Analiz } & & \multicolumn{6}{|c|}{ Karışımlar ve aşı } \\
\hline & & Aşı & Karışım-1 & Karışım-2 & Karışım-3 & Karışım-4 & Karışım-5 \\
\hline \multirow{2}{*}{$\% \mathrm{C}$} & Başlangıç & 33.08 & 32.48 & 31.72 & 32.30 & 34.29 & 36.52 \\
\hline & Son & 30.14 & 29.88 & 28.92 & 29.56 & 31.12 & 34.08 \\
\hline \multirow{2}{*}{$\% N$} & Başlangıç & 2.08 & 2.14 & 2.12 & 2.07 & 2.16 & 2.15 \\
\hline & Son & 1.95 & 2.01 & 1.96 & 1.90 & 2.03 & 2.02 \\
\hline \multirow{2}{*}{$\mathrm{C} \mathrm{N}^{-1}$} & Başlangıç & 15.90 & 15.20 & 14.96 & 15.60 & 15.88 & 16.99 \\
\hline & Son & 15.46 & 14.86 & 14.75 & 15.56 & 15.33 & 16.87 \\
\hline \multirow{2}{*}{ KOi (mg L L-1) } & Başlangıç & 9544 & 17791 & 23549 & 26958 & 29046 & 29430 \\
\hline & Son & 4999 & 12121 & 13410 & 19197 & 15331 & 17499 \\
\hline \multirow{2}{*}{$\mathrm{EC}\left(\mu \mathrm{S} \mathrm{cm^{-1 } )}\right.$} & Başlangıç & 7.96 & 9.17 & 9.67 & 10.26 & 10.61 & 10.55 \\
\hline & Son & 8.86 & 10.39 & 10.81 & 10.88 & 10.74 & 10.71 \\
\hline \multirow{2}{*}{$\mathrm{pH}$} & Başlangıç & 7.80 & 7.85 & 7.60 & 7.40 & 7.29 & 7.24 \\
\hline & Son & 7.73 & 7.61 & 7.32 & 7.17 & 7.09 & 7.04 \\
\hline \multirow{2}{*}{$\% \mathrm{KM}$} & Başlangıç & 6.91 & 7.02 & 7.01 & 6.98 & 7.01 & 7.03 \\
\hline & Son & 6.23 & 6.11 & 6.07 & 5.95 & 5.46 & 5.78 \\
\hline \multirow{2}{*}{$\% O K M$} & Başlangıç & 65.12 & 68.9 & 72.15 & 75.47 & 79.14 & 80.63 \\
\hline & Son & 61.06 & 62.4 & 66.31 & 67.53 & 71.11 & 73.87 \\
\hline \multirow{2}{*}{$\% A D F$} & Başlangıç & 28.01 & 24.03 & 28.07 & 33.16 & 36.47 & 38.49 \\
\hline & Son & 21.46 & 20.47 & 22.63 & 26.58 & 29.77 & 31.44 \\
\hline \multirow{2}{*}{$\% N D F$} & Başlangıç & 35.43 & 28.78 & 34.71 & 41.46 & 53.44 & 64.59 \\
\hline & Son & 27.32 & 22.44 & 26.74 & 31.45 & 40.16 & 54.12 \\
\hline
\end{tabular}


Kimyasal analiz sonuçlarına göre karışımlarda $\mathrm{C}, \mathrm{N}, \mathrm{C} \mathrm{N}^{-1}$, $\mathrm{KM}, \mathrm{OKM}, \mathrm{KOI}, \mathrm{pH}, \mathrm{ADF}$ ve NDF'de azalma $E C^{\prime}$ de ise artma gerçekleşmiştir (Çizelge 4). Karışımlarda; $\mathrm{C}, \mathrm{N}, \mathrm{C} \mathrm{N}^{-}$ 1, KM, OKM, KOI, $\mathrm{pH}$, ADF ve NDF'de deneme sonrası azalma olmasının nedeni biyogaz ve metan üretiminde bakterilerin; kimyasal fonksiyonları için enerji kaynağı olarak C'nu da hücresel fonksiyonların onarımı için N'u materyalleri besin ve enerji kaynağı olarak kullanmasıyla KM'de, şeker, yağ, protein ve diğer organik maddelerini yaşam koşulları ve besin amaçlı kullanmasıyla OKM'de, anaerobik fermantasyon sonucu karbonlu organik maddelerin karbondioksit ve suya dönüşmesiyle KOI'de, anaerobik fermantasyon esnasında asitleşmeye sebep olmasıyla pH'da, selüloz, hemiselüloz ve lignini kullanmasıyla ADF ve NDF'de azalma gerçekleşmiştir. EC değerinde artma olmasının nedeni ise bakterilerin besin olarak biyogaz cürufunu kullanarak kuru madde oranını azaltmaya sebep olmasından kaynaklandığı söylenebilir. $\mathrm{BMP}$ denemesinde deney başlangıç ve sonrası cüruf parametrelerinde; varyans analiz sonucu $\mathrm{C}, \mathrm{N}, \mathrm{C} \mathrm{N}^{-1}$, KOi, $\mathrm{EC}, \mathrm{pH}, \mathrm{KM}, \mathrm{OKM}, \mathrm{ADF}$ ve NDF kimyasal analizlerinde deney başlangıç-sonrası, karışımlar ve deney başlangıçson*karışım intereaksiyonu istatiksel olarak önemli düzeyde bulunmuştur $(P<0.05)$.

BMP denemesinde $\mathrm{C}, \mathrm{N}, \mathrm{C} \mathrm{N}^{-1}, \mathrm{KOI}, \mathrm{EC}, \mathrm{pH}, \mathrm{KM}, \mathrm{OKM}$, ADF ve NDF kimyasal analizleri karışımlar arasında önemli farklılık görülmüştür $(P<0.05)$.

BMP denemelerinde beş farklı karışımda elde edilen deney başlangıç ve sonrasında cüruf parametrelerinde; en yüksek değişim $N, K M, p H$ değeri Karışım-1'de, $K M$ değeri Karışım-2'de $C, C^{-1}$ ve KOi değeri Karışım-5'de olurken en düşük değişim ise; $C, C^{-1}, K O I, E C, O K M, A D F$ ve NDF değeri Karışım-1'de, KM değeri Karışım-1'de ve pH değeri Karışım-5'de meydana gelmiştir (Çizelge 5).

Çizelge 5. BMP denemelerinde cüruf parametrelerinin ortalama değerleri ve önem testi*

Table 5. Average values and significance test of slag parameters in BMP trials

\begin{tabular}{lccccc}
\hline Değiş̧kenler & Karışım- 1 & Karışıım-2 & Karı̧̧ım-3 & Karışım-4 & Karışım-5 \\
\hline $\mathrm{C}$ & $29.97 \mathrm{~d}$ & $30.66 \mathrm{cb}$ & $30.85 \mathrm{c}$ & $33.99 \mathrm{~b}$ & $35.21 \mathrm{a}$ \\
$\mathrm{N}$ & $2.24 \mathrm{a}$ & $2.18 \mathrm{~b}$ & $2.08 \mathrm{c}$ & $2.09 \mathrm{c}$ & $2.14 \mathrm{~b}$ \\
$\mathrm{C} \mathrm{N}^{-1}$ & $13.38 \mathrm{~d}$ & $14.02 \mathrm{c}$ & $14.75 \mathrm{~b}$ & $16.18 \mathrm{a}$ & $16.39 \mathrm{a}$ \\
KOi & $14937 \mathrm{e}$ & $18443 \mathrm{~d}$ & $22169 \mathrm{c}$ & $23051 \mathrm{~b}$ & $23460 \mathrm{a}$ \\
$\mathrm{EC}$ & $9.78 \mathrm{e}$ & $10.23 \mathrm{~d}$ & $10.56 \mathrm{c}$ & $10.67 \mathrm{a}$ & $10.62 \mathrm{~b}$ \\
$\mathrm{pH}$ & $7.71 \mathrm{a}$ & $7.45 \mathrm{~b}$ & $7.27 \mathrm{c}$ & $7.19 \mathrm{~d}$ & $7.14 \mathrm{e}$ \\
$\mathrm{KM}$ & $6.55 \mathrm{a}$ & $6.53 \mathrm{a}$ & $6.47 \mathrm{~b}$ & $6.22 \mathrm{~d}$ & $6.38 \mathrm{c}$ \\
$\mathrm{OKM}$ & $65.74 \mathrm{e}$ & $69.34 \mathrm{~d}$ & $71.54 \mathrm{c}$ & $75.17 \mathrm{~b}$ & $77.30 \mathrm{a}$ \\
$\mathrm{ADF}$ & $22.25 \mathrm{e}$ & $25.32 \mathrm{~d}$ & $29.82 \mathrm{c}$ & $32.94 \mathrm{~b}$ & $34.88 \mathrm{a}$ \\
$\mathrm{NDF}$ & $25.52 \mathrm{e}$ & $30.52 \mathrm{~d}$ & $36.39 \mathrm{c}$ & $46.73 \mathrm{~b}$ & $59.36 \mathrm{a}$ \\
\hline
\end{tabular}

*: Satır içerisinde aynı harfleri alan değerler arasında istatiksel olarak anlamlı bir fark yoktur $(\mathrm{P}<0.05)$.

- Sonuç olarak, biyogaz parametrelerinin (metan oranı, günlük biyogaz üretimi, günlük metan üretimi, kümülatif biyogaz üretimi, kümülatif metan üretimi, özgül metan üretimi) en yüksek değerleri Karışım-4 (\%20 Makroalg+\%80 Büyükbaş hayvan dışkısı)'de, en düşük değerleri ise Karışım-1 (\%100 Makroalg)'de oluşmuştur.

- En yüksek biyogaz parametrelerinin elde edildiği Karışım-4' de, $\mathrm{C} \mathrm{N}^{-1}$ oranı 14.56, olarak elde edilmiştir.

- Karışım-4 (\%20 Makroalg+\%80 Büyükbaş hayvan dışkısı) için maksimum metan oranı \%60-62 arasında bulunmuştur.

- Tüm karışımlarda, anaerobik fermantasyon sonucunda, cüruf paremetrelerinden $\mathrm{C}, \mathrm{N}, \mathrm{C} \mathrm{N}^{-1}, \mathrm{KOI}$, $\mathrm{pH}, \mathrm{OKM}, \mathrm{ADF}$ ve NDF'de azalma, $\mathrm{EC}^{\prime}$ de ise artma gerçekleşmiştir.

- Biyogaz parametrelerinin (günlük biyogaz üretimi, günlük metan üretimi, kümülatif biyogaz üretimi, kümülatif metan üretimi, özgül metan üretimi) karışımlar arasında istatiksel olarak önemli düzeyde $(\mathrm{P}<0.05)$ bulunmuştur

Elde edilen bulgular ve değerlendirmeler sonucunda konuya ilişkin aşağıdaki öneriler sıralanabilir:

- Büyükbaş hayvan dışkısı ve makroalgin en uygun karışımlarda ko-fermantasyonu sonucunda biyogaz ve cüruf parametrelerinin üretim verimlilikleri arttırılabilir.

- Büyükbaş hayvan dışkısı ve makroalg karışımlarında, $C^{-1}$ oranı 14-16 alınarak en uygun biyogaz verimi sağlanabilir.

- Büyükbaş hayvan dışkısı ve makroalgin biyogaz amaçlı kullanılması durumunda ortaya çıkacak yeni materyallerin (cüruf) tarımda fermente gübre amaçlı kullanımı sağlanabilir. 
- Makroalgler, biyogaz tesislerinde materyal olarak kullanılabilir. Böylece tatlı su alanlarında atık, koku vb çevresel sorunların önününe geçilebilir.

- Bu çalışma, 60 bin büyükbaş hayvan kapasiteli, tarıma dayalı intisas büyükbaş besi organize sanayi bölgesinden biri olan ve alg materyalinin alındığı Kahramanmaraş Elbistan ilçesinde kurulabilecek biyogaz tesisinde, büyükbaş hayvan ve makroalglerin en iyi kuru madde ve karışım oranında kullanılmasına katkı sağlayarak enerji verimliliğini artırabilecektir.

\section{ÖZET}

Amaç: Bu çalışmanın amacı, biyogaz tesisleri için hammadde olarak kullanılabilecek büyükbaş hayvan dışkısı ve makroalg materyallerinin, en uygun karışım oranlarında, ko-fermantasyonu ile biyogaz ve metan verimlerinin belirlenmesidir.

Yöntem ve Bulgular: Biyogaz elde etmek amacıyla potansiyel belirlemeye yönelik biyometan potansiyel (BMP) denemeleri kullanılmıştır. Çalışmada, büyükbaş hayvan dışkısı ve makroalg materyallerinin; \%7 kuru madde oranında (KM), karbon azot ${ }^{-1}\left(\mathrm{C} \mathrm{N}^{-1}\right)$ oranına göre 5 farklı karışım (\%100 Makroalg (Karışım-1), \%69 Makroalg+\%31 Büyükbaş hayvan dışkısı (Karışım-2), \%42 Makroalg+\%58 Büyükbaş hayvan dışkısı (Karışım-3), \%20 Makroalg+\%80 Büyükbaş hayvan dışkısı (Karışım-4) ve \%100 Büyükbaş hayvan dışkısı (Karışım-5)) oluşturulmuştur. Kimyasal içeriklerin belirlenmesine yönelik, kuru madde analizi (KM), ham kül (HK), organik kuru madde içeriği (OKM), (karbon (C), azot (N), $\mathrm{C} \mathrm{N}^{-1}$, $\mathrm{pH}$, elektriksel iletkenlik (EC), kimyasal oksijen ihtiyacı (KOI), nötr deterjanda çözünmeyen lif (NDF) ve asit deterjanda çözünmeyen lif (ADF) değerleri belirlenmiştir. BMP denemelerinde oluşturulan karışımların; metan oranı \%25-62, günlük biyogaz üretimi 0.02-1.61 L gün ${ }^{-1}$, günlük metan üretimi 0.01$0.94 \mathrm{~L}_{\text {gün }}{ }^{-1}$, kümülatif biyogaz üretimi $2.5-27.42 \mathrm{~L}$, kümülatif metan üretimi 1.15-15.77 L, özgül metan üretimi 10.67-186.41 $\mathrm{NmL} \mathrm{gOM}^{-1}$ olarak bulunmuştur.

Genel Yorum: BMP denemelerinde en yüksek biyogaz parametreleri Karışım-4'te meydana gelmiştir.

Çalışmanın Önemi ve Etkisi: Canlı hayvan üretiminin artmasına bağlı olarak çok fazla organik materyal oluşmakta ve bu materyallerin yönetiminin uygun yapılamaması önemli çevre ve sağlık problemlerini meydana getirmektedir. Oluşan risk ve zararları en az düzeye indirmek için bu materyallerin doğru kullanımı biyogaz olarak değerlendirilebilir. Ayrıca, tatlı su alanlarında alglerden kaynaklı atık, koku vb çevresel sorunların giderilmesine yönelik olarak algler büyükbaş hayvan dışkısı ile uygun oranlarda karıştırılarak biyogaz tesislerinde enerji ve fermente gübre üretim materyali olarak kullanılabilir.

Anahtar Kelimeler: Büyükbaş hayvan dışkısı, makroalg, biyogaz, biyometan, kimyasal analiz.

\section{TEŞEKKÜR}

Bu çalışma birinci yazarın doktora tezinin bir bölümüdür. Isparta Uygulamalı Bilimler Üniversitesi, Ziraat Fakültesi Tarım Makineleri ve Teknolojileri Mühendisliği Bölümüne laboratuvar imkanlarını sağlamasından dolayı teşekkür ederiz.

\section{ÇIKAR ÇATIŞMA BEYANI}

Yazarlar çalışma konusunda çıkar çatışmasının olmadığını beyan eder.

\section{ARAŞTIRMACILARIN KATKI ORANI BEYANI}

Yazarlar çalışmaya eşit oranda katkı sağlamış olduklarını beyan ederler.

\section{KAYNAKLAR}

AOAC (1990) Official Methods of Analysis. 15th ed. association of official analytical chemists, Washington, DC. US.

Aybek A, Üçok S, İspir MA, Bilgili ME (2015) Türkiye'de kullanılabilir hayvansal gübre ve tahıl sap atıklarının biyogaz ve enerji potansiyelinin belirlenerek sayısal haritalarının oluşturulması. Tekirdağ Ziraat Fakültesi Dergisi 12(3): 109-120.

Beily ME, Morici G, Crespo D, Schapiro J (2019) Biochemical methane potential of sheep manure: Focus in pathogen removal. International Organization of Scientific Research.

Bukvic Z, Kralik D, Tolisic Z (2002). Biomass Methane. Energy Efficiency and Agricultural Engineering. Conference Procedings, 1: 264-270. Rousse, Bulgaria.

Delborne JA, Hasala D, Wigner A, Kinchy A (2020) Dueling metaphors, fueling futures: "Bridge fuel" visions of coal and natural gas in the United States. Energy Research \& Social Science 61: 101350.

Demir N, Yavuz H, Perendeci A, Çakıroğlu C, Celebı SS (2003) Pınarbaşı Göleti'nde (Afşin-Elbistan, Kahramanmaraş) Su Bitkileri Biyokütlesinin İncelenmesi ve Yönetim Metotlarının Değerlendirilmesi. Tarım Bilimleri Dergisi (9)2: 153161.

Dok M, Acar M, Çelik, A, Atagün G, Akbaş U. (2019) Yenilenebilir enerji kaynağı olarak mısır sapının briketlenmesi ve briket fiziksel özelliklerinin 
belirlenmesi. Mustafa Kemal Üniversitesi Tarım Bilimleri Dergisi 24: 61-70.

Ekinci K, Üçok S, Kumbul B S, Tunce H, Güzel H (2018a) Biomethane Potential of Safflower Harvest Residues. Scientific Papers 41.

Ferrentino R, Merzari F, Fiori L, Andreottola G. (2019) Biochemical methane potential tests to evaluate anaerobic digestion enhancement by thermal hydrolysis pretreatment. BioEnergy Research 12(3): 722-732.

Güneş M (1999) Fotovoltaik sistemin sağladığı elektrik enerjisi ile çalışan bir uygulama sisteminin tasarımı, Yüksek Lisans Tezi, Elazı̆g.

Güngör G. (2002) Anaerobic treatibility and biogas generation potential of broiler and cattle manure. A Master of ScienceThesis, METU, Ankara.

Gürbüz A. (2009). Enerji piyasası đçinde yenilenebilir (temiz) enerji kaynaklarının yeri ve önemi, Uluslararası ileri Teknolojiler Sempozyumu (IATS'09), 1-7, 13-15 Mayıs 2009, Karabük.

Höök M (2020) Coal and Peat: Global resources and future supply. Fossil Energy 309-331.

IEA (2013) International energy agency world energy outlook 2013, International Energy Agency Paris.

ISO 6060 (1986) Determination of the chemical oxygen demand, international standards organization, Geneva, İsviçre.Optimising methane yield from anaerobic digestion of manure: Effects of dairy systems and of glycerine supplementation. International Congress Series 1293: 217-220.

Karaca C. (2017). Hatay ilinin hayvansal gübre kaynağından üretilebilir biyogaz potansiyelinin belirlenmesi. Mustafa Kemal Üniversitesi Ziraat Fakültesi Dergisi 22(1): 34-39.

Kapluhan E (2014). Enerji Coğrafyası Açısından Bir Inceleme: Biyokütle Enerjisinin Dünyadaki ve Türkiye'deki Kullanımı. Marmara Coğrafya Dergisi, Sayı: 30, Temmuz - 2014, s.97-125.

Korkmaz E (2017) Marmara denizinden toplanan atık makroalglerin organik atıklarla birlikte biyogaz üretim potansiyelinin değerlendirilmesi, Yıldız Teknik Üniversitesi Fen Bilimleri Enstitüsü İstanbul, Yüksek lisans tezi ss: 71.

Montingelli ME, Benyounis KY, Stokes J, Olabi AG (2016) Pretreatment of macroalgal biomass for biogas production. Energy conversion and management 108: 202-209.

Onursal E (2016) Gül işleme atıklarından biyogaz üretiminde etkili faktörlerin optimizasyonu ve ekonomik analizi. Süleyman Demirel Üniversitesi Fen Bilimleri Ensitüsü Doktora tezi.
Oktit Ş (2000) Fotovoltaik güneş pilleri ve güç sistemleri dünü, bugünü, yarını", Türkiye'de 8. Enerji Kongresi, Yeni ve Yenilenebilir Enerji Kaynaklarının Gelişimi, Cilt II, Ankara, 47-62.

Oliveira JV, Alves MM, Costa JC (2014) Design of experiments to assess pre-treatment and codigestion strategies that optimize biogas production from macroalgae Gracilaria vermiculophylla. Bioresource Technology 162: 323330.

Roesijadi G, Jones SB, Snowden-Swan LJ, Zhu Y (2010) Macroalgae as a biomass feedstock: a preliminary analysis (No. PNNL-19944). Pacific Northwest National Lab.(PNNL), Richland, WA (United States).

Sarapatka B (1993) A Study of Biogas Production during anaerobic fermentation of farmyard manure, Biomass and Bioenergy 5(5): 387-393

Sun O, Uğurlu S, Özer E (1980) Kızılçam türüne ait biyolojik kütlenin saptanması. O.A.E Yayınları. Teknik Bülten Serisi. No :107. Sa : 37- 50. Ankara.

Tabatabaei M, Aghbashlo M, Valijanian E, Panahi HKS, Nizami AS, Ghanavati H, Karimi K (2020). A comprehensive review on recent biological innovations to improve biogas production, part 1 : upstream strategies. Renewable Energy 146: 12041220.

TUiK (2016) Türkiye İstatistik Kurumu. Konularına Göre İstatistikler, Tarım. http://www.tuik.gov.tr/UstMenu.do?metod=katego ri st (Erişim: 07.01 2017).

Üçok S (2016) Sebze ve Meyve Pazar Atiklarinin Biyogaz Üretim Potansiyelinin Belirlenmesi Üzerine Bir Araştirma. Kahramanmaraş Sütçü İmam Üniversitesi, Fen Bilimleri Entsitüsü, Yüksek Lisans Tezi, $52 \mathrm{~s}$.

Vansoset PJ, Robertson JB, Lewis BA (1991) Method for dietary fiber, neutral detergent fiber, and nostarch polysaccharides in relation to animal nutrition. J. Dairy Sci.74: 3583-3597.

Yorgun S, Şensöz S, Şölener M (1998) Biyokütle enerjisi potansiyeli ve değerlendirme çalışmaları. Uzman Enerji 8: 44-48.

Wilkie CA (2015) Erişim tarihi: 12/2018, http://biogas.ifas.ufl.edu/biogasdefs.asp. 